\title{
The effect of the nitrification inhibitor dicyandiamide (DCD) on herbage production when applied at different times and rates in the autumn and winter
}

\author{
P.J. O'Connor ${ }^{\mathrm{a}, \mathrm{b}}$, D. Hennessy ${ }^{\mathrm{a}, *}$, C. Brophy ${ }^{\mathrm{c}}$, M. O’Donovan ${ }^{\mathrm{a}}$, M.B. Lynch $^{\mathrm{b}}$ \\ a Teagasc, Animal \& Grassland Research and Innovation Centre, Moorepark, Fermoy, Co. Cork, Ireland \\ ${ }^{\mathrm{b}}$ UCD School of Agriculture and Food Science, University College Dublin, Belfield, Dublin 4, Ireland

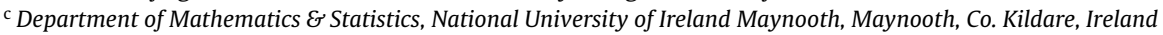

\section{A R T I C L E I N F O}

\section{Article history:}

Received 15 June 2011

Received in revised form 15 February 2012

Accepted 19 February 2012

\section{Keywords:}

Herbage production

Nitrification inhibitor

Dicyandiamide

Urine

Soil mineral $\mathrm{N}$

$\mathrm{N}$ uptake

\begin{abstract}
A B S T R A C T
The high rate of urine excreted during animal grazing in late autumn provides a source of nitrogen (N) to the growing sward and also provides the potential for losses of $\mathrm{N}$ over the winter months. This study was established to evaluate the potential of applying a nitrification inhibitor, dicyandiamide (DCD), to urine patches to increase $\mathrm{N}$ use efficiency in grassland. Four simulated grazing plot experiments were undertaken across two experimental sites, one a free-draining acid brown earth (Experiments 1 and 3 ) and the other a moderate to heavy brown earth soil (Experiments 2 and 4). Experiments 1 and 2 received no fertiliser $\mathrm{N}$ application, and Experiments 3 and 4 received a split application of $350 \mathrm{~kg} \mathrm{~N}$ fertiliser $\mathrm{ha}^{-1}$ year $^{-1}$. The effect of applying the nitrification inhibitor dicyandiamide (DCD) at 5 or $10 \mathrm{~kg} \mathrm{DCD} \mathrm{ha}^{-1}$ in autumn and winter to plots receiving synthetic urine or zero urine on spring and annual herbage production was examined in all experiments. The application of DCD did not increase spring herbage production in any of the experiments. Over the two years, the application of 5 or $10 \mathrm{~kg} \mathrm{DCD} \mathrm{ha}^{-1}$ increased annual herbage production in Experiment 1 when applied to October and November deposited urine patches. Urine application increased herbage production in spring and annually in Experiments 1 and 2 , and increased herbage crude protein content and herbage $\mathrm{N}$ uptake in all experiments. The application of urine increased soil ammonium and TON content in the $0-100 \mathrm{~mm}$ horizon at both sites. The application of $10 \mathrm{~kg} \mathrm{DCD} \mathrm{ha}{ }^{-1}$ reduced surplus $\mathrm{N}$ in Experiment 1 when applied to October and November deposited urine. Overall the effects of DCD on herbage production, surplus $\mathrm{N}$ and other parameters in this study were not consistent.
\end{abstract}

(c) 2012 Elsevier B.V. All rights reserved.

\section{Introduction}

Increasing the proportion of grazed grass in the diet of the dairy cow, particularly in early spring, reduces milk production costs and can increase the profitability of grass based milk production systems in Ireland and other temperate climates (Shalloo et al., 2004; Dillon et al., 2005; Kennedy et al., 2005). Nitrogen (N) availability is one of the key factors driving grass growth. Increasing $\mathrm{N}$ availability in spring through fertiliser or slurry application can result in increased grass growth and therefore herbage availability for grazing. Urine and dung are also sources of $\mathrm{N}$ in grazed swards, although their deposition is localised. Nitrogen concentration under urine patches is very high, equivalent to a fertiliser $\mathrm{N}$ application rate of up to $1000 \mathrm{~kg} \mathrm{Nha}^{-1}$ (Whitehead, 1995). The majority of this $\mathrm{N}$ is in excess of sward requirements and is often lost by nitrate $\left(\mathrm{NO}_{3}{ }^{-}\right)$

\footnotetext{
* Corresponding author. Tel.: +353025 42297; fax: +353025 4234

E-mail address: deirdre.hennessy@teagasc.ie (D. Hennessy).
}

leaching through the soil profile or nitrous oxide $\left(\mathrm{N}_{2} \mathrm{O}\right)$ emissions, particularly over winter when grass growth rates are low.

Nitrification inhibitors are being investigated in many countries as a strategy to mitigate $\mathrm{NO}_{3}{ }^{-}$leaching, denitrification and $\mathrm{N}_{2} \mathrm{O}$ emissions under urine patches (Serna et al., 1995). They therefore have the potential to increase $\mathrm{N}$ availability in the soil for grass growth, thereby increasing the $\mathrm{N}$ use efficiency of grazed swards, as well as reducing $\mathrm{N}$ losses to the environment (O'Connell et al., 2004). Dicyandiamide (DCD; $\mathrm{C}_{2} \mathrm{H}_{4} \mathrm{~N}_{4}$ ) is one such nitrification inhibitor. It is a white crystalline nitrogenous powder naturally broken down in the soil, with no traces of residue remaining beyond the cropping year (Amberger, 1989). Dicyandiamide slows the conversion of ammonium $\left(\mathrm{NH}_{4}{ }^{+}\right)$to $\mathrm{NO}_{3}{ }^{-}$in the soil by interfering with the cytochrome oxidase in the respiratory electron transport system of Nitrosomonas bacteria, which are responsible for the first step of the nitrification process (Serna et al., 1995). Reductions in $\mathrm{NO}_{3}{ }^{-}$leaching and $\mathrm{N}_{2} \mathrm{O}$ emissions following the application of DCD have been reported by many authors including Moir et al. (2007) and Dennis et al. (2008). Di and Cameron (2002) reported reductions in annual $\mathrm{NO}_{3}{ }^{-}$leaching of $59 \%$ from urine 
patches (lysimeter study) following DCD application; in addition Di and Cameron (2005) reported a 68\% reduction in $\mathrm{NO}_{3}{ }^{-}$leaching from dairy cow urine $\mathrm{N}$ when DCD was applied in autumn (Di and Cameron, 2005). Selbie et al. (2011) reported that DCD $\left(10 \mathrm{~kg} \mathrm{ha}^{-1}\right)$ reduced $\mathrm{NO}_{3}{ }^{-}$leaching by $45 \%$ and $\mathrm{N}_{2} \mathrm{O}$ emissions by $70 \%$ on dairy cow urine $\left(1000 \mathrm{~kg} \mathrm{Nha}^{-1}\right)$ treatments on Irish soils. Richards et al. (2008) also reported that DCD application on urine patches reduced $\mathrm{NO}_{3}{ }^{-}$leaching, especially on Irish soils.

In addition to the reductions in environmental $\mathrm{N}$ losses, $\mathrm{Di}$ and Cameron (2002) also observed an 18\% increase in herbage production following DCD application to spring deposited urine patches, and an average increase in herbage production of $49 \%$ following DCD application to autumn deposited urine patches. The same authors observed that the application of DCD to autumn deposited urine patches, followed by a second application in spring, increased herbage production by 33\% annually (Di and Cameron, 2005). Zaman and Blennerhassett (2010) reported that the application of DCD to spring deposited urine increased herbage production by an average of $12 \%$.

An $\mathrm{N}$ balance can be used to describe the potential for $\mathrm{N}$ loss to the environment; it gives an indication of the quantity of $\mathrm{N}$ that may be lost through leaching, denitrification and volatilization or immobilization into soil organic N. Research has identified the importance of some individual loss processes, such as $\mathrm{N}$ losses by ammonia volatilization in pastures grazed by dairy cows (Bussink and Oenema, 1996), $\mathrm{NO}_{3}{ }^{-}-\mathrm{N}$ leaching (Scholefield et al., 1993), $\mathrm{N}_{2} \mathrm{O}$ emissions and N removal by immobilization (Ledgard et al., 1999).

The efficacy of DCD is influenced by several factors, including soil and environmental factors. Temperature is the most influential environmental factor; an increase in temperature can have a negative effect on the persistence of DCD in the soil, reducing the time frame in which it can provide effective nitrification inhibition. The half life of DCD at $6^{\circ} \mathrm{C}$ is 100 days (Williamson et al., 1996), and 18-25 days at $20^{\circ} \mathrm{C}$ (Di and Cameron, 2004). As a consequence, DCD should be applied in cool conditions such as late autumn, winter and early spring in temperate climates to maximise its potential effectiveness in inhibiting nitrification in the soil (Kelliher et al., 2008). Therefore, the hypothesis of this experiment was that the application of DCD in autumn and winter will increase N availability for grass growth in spring and, therefore, increase spring herbage production.

The objective of this study was to establish if herbage production was increased following the application of DCD to autumn and winter deposited urine patches, and to determine the appropriate rate and time of application of DCD on grass swards receiving zero or $350 \mathrm{~kg} \mathrm{~N} \mathrm{ha}^{-1}$ year $^{-1}$.

\section{Materials and methods}

\subsection{Soil type and pasture}

Four experiments were undertaken using simulated grazing plots at the Animal and Grassland Research and Innovation Centre, Teagasc, Moorepark, Fermoy, Co. Cork, Ireland, on two contrasting soil types. The soils were a free-draining acid brown earth of sandy loam to loam in texture with a pH of 6.02 and bulk density of $1.00 \mathrm{~g} \mathrm{~cm}^{3}$ at Moorepark Research Farm, hereafter referred to as MPK $\left(50^{\circ} 07^{\prime} \mathrm{N}, 08^{\circ} 16^{\prime} \mathrm{W}\right)$ in Experiments 1 and 3 and a moderate to heavy brown earth with evidence of an iron pan with a pH of 5.52 and bulk density of $0.83 \mathrm{~g} \mathrm{~cm}^{3}$ at Ballydague Research Farm, hereafter referred to as $\mathrm{BD}\left(52^{\circ} 12^{\prime} \mathrm{N}, 08^{\circ} 13^{\prime} \mathrm{W}\right)$ in Experiments 2 and 4. Ballydague Research Farm is approximately $8 \mathrm{~km}$ from MPK. Swards were predominately perennial ryegrass (Lolium perenne L.) and were previously rotationally grazed by dairy cows at MPK and by dairy heifers at BD. In Experiments 1 and 2 no fertiliser $\mathrm{N}$ was applied, and in Experiments 3 and 4 split applications of $\mathrm{N}$ fertiliser (total $350 \mathrm{~kg} \mathrm{Nha}^{-1}$ year $^{-1}$ ) were applied between mid-January and mid September (as specified in the Irish Governments Nitrates Action Plan (S.I. 378, 2006)) as urea (46\% N) from February to April (120 kg N ha ${ }^{-1}$ year $^{-1}$ ), and calcium ammonium nitrate (CAN; $27 \%$ N) from May to September $\left(230 \mathrm{~kg} \mathrm{Nha}^{-1}\right.$ year $\left.^{-1}\right)$.

\subsection{Experimental design}

Apart from the $\mathrm{N}$ fertiliser application strategy (zero $\mathrm{N}$ in Experiments 1 and 2, and $350 \mathrm{~kg} \mathrm{Nha}^{-1}$ in Experiments 3 and 4), all experiments had the same design. Each experiment had three replications (blocks), and within each replication five factors (details below) were manipulated resulting in 28 treatments in total. The 28 treatments were each applied to one plot within each block; plots were $5 \mathrm{~m} \times 1 \mathrm{~m}$ at BD and $5 \mathrm{~m} \times 1.5 \mathrm{~m}$ at MPK. Experiments were established in September 2008 and completed in November 2010. A cleaning cut was undertaken in November 2008 and the recording of experimental data began in February 2009. Each plot was harvested ten times in year 1 (2009) and eight times in year 2 (2010).

\subsection{Treatments}

Within each experiment, the five factors manipulated were urine rate, date of application of urine, DCD rate, date of first application of DCD and date of second application of DCD (Table 1). The two urine application rates were 0 and $1000 \mathrm{~kg} \mathrm{Nha}^{-1}$ (OU or U, respectively) applied on one of three occasions in autumn - late September, October or November. Synthetic urine was used (urea and water mix) so that a known quantity of N was applied. Synthetic urine was deposited using $10 \mathrm{~L}$ watering cans with rose caps (cap with small openings). Dicyandiamide was applied at rates of 0 , 5 and $10 \mathrm{~kg} \mathrm{ha}^{-1}$ to all designated plots within $24 \mathrm{~h}$ of urine application in either late September, October or November. Of the plots that received a first application of $D C D>0 \mathrm{~kg} \mathrm{ha}^{-1}$, half received a second application of the same rate approximately 90 days later. The DCD was applied as a fine particle suspension (FPS) using a walk behind sprayer (Kestrel Spray-Master Sprayer, R\&J Hay, St Johnston, Cavanacaw, Co. Donegal, Ireland).

Plots receiving DCD at rates of 0,5 and $10 \mathrm{~kg} \mathrm{ha}^{-1}$ will hereafter be referred to as 0,5 and 10 . Plots receiving a single application of urine and DCD in late September, October or November will hereafter be referred to as $\mathrm{S}, \mathrm{O}$ or $\mathrm{N}$, and those receiving a second application of DCD 90 days later will hereafter be referred to as $\mathrm{S}+90, \mathrm{O}+90$ and $\mathrm{N}+90$. Plots that received zero urine and zero DCD are called control and hereafter be referred to as $C$. In total there are 28 unique combinations of factor levels or treatments (including control) listed in Table 1 . Treatments applied in year 1 were applied between September 2008 and March 2009 and treatments applied in year 2 were applied between September 2009 and March 2010.

\subsection{Measurements}

\subsubsection{Herbage production}

Herbage was mechanically harvested every four weeks from February to November 2009 and in 2010 using an Agria auto-scythe mower (Agria Werke GmbH, Bittelbronnerstr 42, Moeckmuehl 74219, Germany) at MPK and a Honda rotary blade lawnmower (Honda HRH 536 HX Pro Hydrostatic 4-wheel mower, Honda, Swepsonville, NC, USA) at BD. The Honda lawnmower was used at $\mathrm{BD}$ due to the heavy soil at the site (Hennessy et al., 2008). All fresh samples were weighed and a sub-sample $(100 \mathrm{~g})$ was dried at $40^{\circ} \mathrm{C}$ for $48 \mathrm{~h}$ to determine dry matter (DM) content. Dry matter yield was calculated by multiplying DM\% of the subsample by 
Table 1

Experimental treatments 1-28; for each of the four experiments, each treatment appeared once in each of three blocks.

\begin{tabular}{|c|c|c|c|c|c|c|}
\hline Treatment \# & Treatment code & Urine $\left(\mathrm{kg} \mathrm{Nha}^{-1}\right)$ & $\begin{array}{l}\text { Date of urine } \\
\text { application }^{\mathrm{a}}\end{array}$ & DCD rate $\left(\mathrm{kg} \mathrm{ha}^{-1}\right)$ & $\begin{array}{l}\text { Date first DCD } \\
\text { application }^{\mathrm{a}, \mathrm{b}}\end{array}$ & $\begin{array}{l}\text { Date of second DCD application } \\
\text { (days post first application) }^{\mathrm{a}}\end{array}$ \\
\hline 1 & C & 0 & 0 & 0 & 0 & 0 \\
\hline 2 & SoU5 & 0 & 0 & 5 & September & 0 \\
\hline 3 & SOU10 & 0 & 0 & 10 & September & 0 \\
\hline 4 & $S+900 U 5$ & 0 & 0 & 5 & September & +90 \\
\hline 5 & $\mathrm{~S}+900 \mathrm{U} 10$ & 0 & 0 & 10 & September & +90 \\
\hline 6 & O0U5 & 0 & 0 & 5 & October & 0 \\
\hline 7 & O0U10 & 0 & 0 & 10 & October & 0 \\
\hline 8 & $0+900 U 5$ & 0 & 0 & 5 & October & +90 \\
\hline 9 & $\mathrm{O}+900 \mathrm{U} 10$ & 0 & 0 & 10 & October & +90 \\
\hline 10 & N0U5 & 0 & 0 & 5 & November & 0 \\
\hline 11 & NOU10 & 0 & 0 & 10 & November & 0 \\
\hline 12 & $\mathrm{~N}+900 \mathrm{U} 5$ & 0 & 0 & 5 & November & +90 \\
\hline 13 & $\mathrm{~N}+900 \mathrm{U} 10$ & 0 & 0 & 10 & November & +90 \\
\hline 14 & SU0 & 1000 & September & 0 & 0 & 0 \\
\hline 15 & SU5 & 1000 & September & 5 & September & 0 \\
\hline 16 & SU10 & 1000 & September & 10 & September & 0 \\
\hline 17 & $\mathrm{~S}+90 \mathrm{U} 5$ & 1000 & September & 5 & September & +90 \\
\hline 18 & $S+90 U 10$ & 1000 & September & 10 & September & +90 \\
\hline 19 & OUO & 1000 & October & 0 & 0 & 0 \\
\hline 20 & OU5 & 1000 & October & 5 & October & 0 \\
\hline 21 & OU10 & 1000 & October & 10 & October & 0 \\
\hline 22 & O+90U5 & 1000 & October & 5 & October & +90 \\
\hline 23 & $\mathrm{O}+90 \mathrm{U} 10$ & 1000 & October & 10 & October & +90 \\
\hline 24 & NU0 & 1000 & November & 0 & 0 & 0 \\
\hline 25 & NU5 & 1000 & November & 5 & November & 0 \\
\hline 26 & NU10 & 1000 & November & 10 & November & 0 \\
\hline 27 & $\mathrm{~N}+90 \mathrm{U} 5$ & 1000 & November & 5 & November & +90 \\
\hline 28 & $\mathrm{~N}+90 \mathrm{U} 10$ & 1000 & November & 10 & November & +90 \\
\hline
\end{tabular}

${ }^{\text {a }}$ In each of the three columns related to date of application 0 indicates that there was no application.

b DCD was applied within $24 \mathrm{~h}$ of urine application.

the fresh weight $\left(\mathrm{kg}^{-1}\right)$ recorded and converted to hectares (Ansah et al., 2010). The responses of annual herbage production (DM was summed over all harvest dates within each year) and spring (February-April, inclusive) herbage production (DM was summed over spring harvest dates within each year) were computed for each plot for each year of the experiments.

\subsubsection{Herbage crude protein content and herbage $N$ uptake}

The dried herbage was subsequently milled through a $1 \mathrm{~mm}$ screen (Tecator Cyclotec 1093 Mill) for chemical analysis. Herbage crude protein $(\mathrm{CP})$ content was determined using near infra-red spectroscopy (NIRS) analysis (NIRS, Model 6500, FOSS-NIR System, 3400 Hillerød, Denmark) and the equation developed by Burns et al. (2010). Herbage N uptake was computed using the following equations:

Herbage $\mathrm{N}$ content

$$
\begin{aligned}
& \left.=\frac{\text { herbage mass }(\mathrm{kg} \mathrm{DM} \mathrm{ha}}{-1}\right) \times \text { herbage } \mathrm{CP} \text { content }\left(\mathrm{g} \mathrm{kg}^{-1}\right) \\
& 6.25 \times 1000
\end{aligned}
$$

Herbage $\mathrm{N}$ uptake $=$ treatment herbage $\mathrm{N}$ content

$$
\text { - control herbage } \mathrm{N} \text { content }
$$

Spring herbage crude protein (averaged over spring harvest dates within each year) and spring herbage $\mathrm{N}$ uptakes (summed over spring harvest dates within each year) were computed for each treatment for the two years of the experiments.

\subsubsection{Soil ammonium and total oxidised nitrogen content}

Soil sampling took place in year 2 on day 7, 14, 28, 56 and 84 post treatment application to determine $\mathrm{NH}_{4}{ }^{+}-\mathrm{N}$ and total oxidised nitrogen (TON) content. Total oxidised nitrogen is $\mathrm{NO}_{3}{ }^{-}$ plus nitrite $\left(\mathrm{NO}_{2}{ }^{-}\right)$. Two soil cores $(0-100 \mathrm{~mm}$ depth and $22.5 \mathrm{~mm}$ diameter) were removed from each plot. Soil samples from each plot were composited and then sieved through a $2 \mathrm{~mm}$ screen to remove debris. Subsamples of $100 \mathrm{~g}$ were dried at $105^{\circ} \mathrm{C}$ for $24 \mathrm{~h}$ to determine DM content. Another subsample of $30 \mathrm{~g}$ was extracted with $2 \mathrm{M} \mathrm{KCl}$ (Merck KGaA, Frankfurter StraBe 250, 64293 Darmdtadt, Germany) solution by shaking for $2 \mathrm{~h}$ using the methodology described by Zaman et al. (1999). The extractant was filtered and frozen until analysis to determine $\mathrm{NH}_{4}{ }^{+}-\mathrm{N}$ and TON content. The $\mathrm{NH}_{4}{ }^{+}-\mathrm{N}$ and TON content in the extractant were measured using an Aquakem 600 Discrete Analyser (Thermo Scientific, Ratastie 2, P.O. Box 100, FI-01621 Vantaa, Finland). Soil bulk density $\left(\mathrm{g} \mathrm{m}^{3}\right)$ was calculated using methodology described by Hao et al. (2008). Soil $\mathrm{NH}_{4}{ }^{+}-\mathrm{N}$ and TON content $\left(\mathrm{kg} \mathrm{N} \mathrm{ha}^{-1}\right)$ were calculated by multiplying $\mathrm{NH}_{4}{ }^{+}-\mathrm{N}\left(\mathrm{mg} \mathrm{kg}^{-1}\right)$ or TON $\left(\mathrm{mg} \mathrm{kg}^{-1}\right)$ by the bulk density. Soil $\mathrm{NH}_{4}{ }^{+}$-N and TON were recorded on each plot repeatedly on five sampling occasions in year 2 of the experiments only.

\subsubsection{Nitrogen balance}

An $\mathrm{N}$ balance was calculated for the urine treatments with and without DCD, and the zero urine treatments, again with and without DCD. An N balance was also calculated for a hypothetical farm system in which $2.77 \%$ of the land area would receive urine patches treated with DCD; $2.77 \%$ represents the land area on which urine was deposited in a single grazing month. Nitrogen surplus was calculated by subtracting $\mathrm{N}$ outputs from $\mathrm{N}$ inputs.

\subsection{Nitrogen inputs}

The $\mathrm{N}$ inputs consisted of fertilizer ( 0 or $350 \mathrm{~kg} \mathrm{Nha}^{-1}$ ) and livestock urine deposition ( 0 or $208.3 \mathrm{~kg} \mathrm{Nha}^{-1}$ ). Annual urine deposition per hectare was calculated using a stocking rate (SR) of $2.5 \mathrm{LU} \mathrm{ha}^{-1}$, urine patch coverage of $20.83 \%$ of pasture area per year, and urine deposition of $1000 \mathrm{~kg} \mathrm{~N} \mathrm{ha}^{-1}$ at each urination 
(Haynes and Williams, 1993). Atmospheric N deposited each year was assumed to be $9 \mathrm{~kg} \mathrm{~N} \mathrm{ha}^{-1}$ as estimated by Ryan et al. (2006).

\subsection{Nitrogen outputs}

The only $\mathrm{N}$ output measured in this study was spring herbage $\mathrm{N}$ uptake, as calculated above. The $\mathrm{N}$ uptake from June to November was calculated using herbage $\mathrm{CP}$ content previously measured at Moorepark by O’Donovan and Kennedy (2007).

\subsection{Meteorological data}

Rainfall, mean daily temperature and soil temperature (measured at $100 \mathrm{~mm}$ soil depth) (Table 2) were recorded at climatological station located at the Animal and Grassland Research and Innovation Centre, Teagasc, Moorepark.

\subsection{Data analysis}

Spring herbage production, annual herbage production, spring herbage $\mathrm{CP}$ content, spring herbage $\mathrm{N}$ uptake and $\mathrm{N}$ balance data were analysed with linear mixed models that allowed for the two repeated measurements (Year 1 and Year 2) fitted using the MIXED procedure in SAS (SAS, 2003). The main factors included in each model were urine rate, urine application date, DCD rate, DCD first application date and DCD second application date. There were two urine rates, 0 and $1000 \mathrm{~kg} \mathrm{~N} \mathrm{ha}^{-1}$. Urine application date had four levels which were 0 (i.e. no application), September, October and November. DCD rate had three levels which were 0,5 and $10 \mathrm{~kg} \mathrm{ha}^{-1}$. DCD first application date had four levels which were 0 (i.e. no application), September, October and November. DCD second application date had two levels which were 0 (i.e. no application) and 90 days after the first application of DCD. Interactions among the variables were also tested. Note that there was some confounding of main effects (Table 1 ) which restricted how some interactions could be tested. For example, when urine was 0 , urine application date also had to be 0 as it was not possible to manipulate date of application when there was no application. A similar situation arises when comparing DCD rate with the two DCD application date variables. Soil $\mathrm{NH}_{4}{ }^{+}-\mathrm{N}$ and TON content were also analysed with linear mixed models that allowed for the repeated measures over the five sampling dates (within the one year of sampling for these responses) and were fitted using the MIXED procedure in SAS. The model included main factors as described above and post treatment sampling day. Data for each experiment were analysed individually.

\section{Results}

\subsection{Meteorological data}

Table 2 shows the mean daily air temperature; mean monthly soil temperature at a depth of $100 \mathrm{~mm}$ and total monthly rainfall for 2008-2010, and the 30 year average (1981-2010) at the Moorepark site. Mean daily air temperatures observed following DCD application in this study were greater than the 30 year average for the months of October of Year 2, November Years 1 and 2, and March Year 1; and was similar or lower than the 30 year average for all other dates. Mean soil temperatures observed in this study were lower than the 30 year average for all application dates except for September Year 1 and March Year 2. Total rainfall in September Year 1, October Years 1 and 2, November Year 2, January Year 1 and March Year 2 were greater than the 30 year average, and was similar or lower to the 30 year average for all other dates.

\subsection{Experiments 1 and 2}

\subsubsection{Herbage production}

Spring herbage production was significantly $(P<0.001)$ reduced in Year 2 compared to Year 1 in both experiments (Tables 3 and 4). In Experiment 2 annual herbage production was significantly $(P<0.001)$ greater in Year 2 compared to Year 1 (Table 4$)$.

Spring herbage production was significantly $(P<0.001)$ increased following urine application in Experiment 1 by $+90 \%$ and in Experiment 2 by $+21 \%$ compared to the $0 \mathrm{U}$ treatments (Tables 3 and 4). Annual herbage production was +36 and $+17 \%$ greater at MPK and BD, respectively, on U treatments compared to OU treatments (Tables 3 and 4).

There was no significant effect of urine application date on spring herbage production in either experiment (Tables 3 and 4). Applying urine in November significantly $(P<0.01)$ increased annual herbage production $(+18 \%)$ in Experiment 1 compared with the September application date (Table 3 ). Applying urine in September significantly $(P<0.01)$ increased annual herbage production in Experiment 2 compared to the two other application dates (Table 4). Applying DCD at a rate of 5 or $10 \mathrm{~kg} \mathrm{ha}^{-1}$ significantly $(P<0.01)$ increased annual herbage production in Experiment 1 by +25 and $+16 \%$, respectively, compared to applying zero DCD (Table 3). There was no significant effect of DCD first application date or DCD second application date on spring or annual herbage production in either Experiment 1 or 2.

There was a significant $(P<0.05)$ interaction between urine application date and DCD rate at MPK on annual herbage production. Treatment OU10 significantly increased annual herbage

Table 2

Total rainfall $(\mathrm{mm})$, mean daily air temperature $\left({ }^{\circ} \mathrm{C}\right)$ and mean soil temperature at $100 \mathrm{~mm}\left({ }^{\circ} \mathrm{C}\right)$ at Moorepark in 2008, 2009, 2010 and 30 year average $(1981-2010)$.

\begin{tabular}{|c|c|c|c|c|c|c|c|c|c|c|c|c|}
\hline & \multicolumn{4}{|c|}{ Total rainfall (mm) } & \multicolumn{4}{|c|}{ Mean daily air temperature $\left({ }^{\circ} \mathrm{C}\right)$} & \multicolumn{4}{|c|}{ Mean soil temperature at $100 \mathrm{~mm}\left({ }^{\circ} \mathrm{C}\right)$} \\
\hline & 2008 & 2009 & 2010 & 30 year average & 2008 & 2009 & 2010 & 30 year average & 2008 & 2009 & 2010 & 30 year average \\
\hline January & 145.0 & 193.7 & 106.8 & 109.2 & 6.7 & 4.5 & 2.2 & 5.4 & 6.2 & 4.1 & 2.3 & 5.1 \\
\hline February & 42.3 & 15.6 & 39.0 & 80.7 & 6.0 & 5.1 & 3.0 & 5.7 & 6.1 & 4.9 & 3.2 & 5.2 \\
\hline March & 110.5 & 56.4 & 88.2 & 85.6 & 6.1 & 7.1 & 5.4 & 6.9 & 6.6 & 7.3 & 5.7 & 6.7 \\
\hline April & 37.7 & 106.7 & 59.3 & 64.8 & 7.9 & 8.9 & 8.5 & 8.5 & 9.1 & 10.2 & 9.9 & 8.9 \\
\hline May & 51.0 & 88.6 & 38.3 & 67.8 & 12.8 & 11.0 & 10.9 & 11.0 & 14.7 & 13.0 & 13.1 & 12.3 \\
\hline June & 94.4 & 51.9 & 52.5 & 69.8 & 13.6 & 14.6 & 15.4 & 13.6 & 16.5 & 17.1 & 17.9 & 15.3 \\
\hline July & 134.8 & 153.8 & 142.7 & 65.9 & 15.1 & 14.8 & 15.8 & 15.5 & 17.2 & 17.6 & 18.2 & 16.8 \\
\hline August & 117.7 & 116.5 & 23.1 & 83.8 & 15.4 & 14.9 & 14.3 & 15.3 & 16.8 & 17.3 & 17.1 & 16.3 \\
\hline September & 89.9 & 41.2 & 102.1 & 80.9 & 12.4 & 12.9 & 13.6 & 13.2 & 13.9 & 14.9 & 15.4 & 13.9 \\
\hline October & 113.2 & 126.7 & 82.6 & 113.0 & 9.2 & 11.8 & 9.9 & 10.2 & 10.2 & 12.9 & 11.1 & 10.9 \\
\hline November & 65.6 & 259.5 & 97.7 & 104.6 & 8.0 & 7.8 & 5.4 & 7.5 & 7.7 & 8.4 & 6.5 & 7.8 \\
\hline December & 50.1 & 82.7 & 36.5 & 104.3 & 5.3 & 3.2 & 0.6 & 5.8 & 4.7 & 4.0 & 1.7 & 6.0 \\
\hline Total & 1052 & 1293 & 869 & 1030 & & & & & & & & \\
\hline
\end{tabular}


Table 3

The effect of DCD applied following urine application on herbage production ( $\left.\mathrm{kg} \mathrm{DM} \mathrm{ha}^{-1}\right)$, crude protein ( $\left.\mathrm{g} \mathrm{kg} \mathrm{g}^{-1} \mathrm{DM}\right)$ and nitrogen uptake ( $\mathrm{kg} \mathrm{N}$ ha $\left.{ }^{-1}\right)$ in Experiment 1.

\begin{tabular}{|c|c|c|c|c|c|}
\hline \multirow[b]{2}{*}{ Measurement period } & \multicolumn{2}{|c|}{$\begin{array}{l}\text { Herbage production } \\
\left(\mathrm{kgDM}^{-1} \mathrm{ha}^{-1}\right)\end{array}$} & \multirow{2}{*}{$\begin{array}{l}\text { Crude protein }\left(\mathrm{g} \mathrm{kg} \mathrm{ha}^{-1}\right) \\
\text { Spring }\end{array}$} & \multirow{2}{*}{$\begin{array}{l}\text { Nitrogen Uptake }\left(\mathrm{kg} \mathrm{ha}^{-1}\right) \\
\text { Spring }\end{array}$} & \multirow{2}{*}{$\begin{array}{l}\text { Surplus } \mathrm{N}\left(\mathrm{kg} \mathrm{ha}^{-1}\right) \\
\text { Annual }\end{array}$} \\
\hline & Spring & Annual & & & \\
\hline \multicolumn{6}{|l|}{ Year } \\
\hline Year 1 & 3027 & 8067 & 246 & 115 & 22 \\
\hline Year 2 & 2617 & 8078 & 234 & 89 & 45 \\
\hline s.e.m. & 60 & 137 & 1.9 & 2.6 & 16.1 \\
\hline Significance & ${ }^{* * *}$ & NS & ${ }^{* * *}$ & ${ }^{* * *}$ & NS \\
\hline \multicolumn{6}{|l|}{ Urine } \\
\hline Zero urine & 1688 & 6341 & 211 & 51 & -33 \\
\hline Urine & 3200 & 8649 & 232 & 119 & 89 \\
\hline s.e.m. & 97 & 222 & 2.6 & 3.9 & 8.2 \\
\hline Significance & ${ }^{* * * *}$ & ${ }^{* * * *}$ & ${ }^{* * *}$ & $* * *$ & $* * *$ \\
\hline \multicolumn{6}{|l|}{ DCD rate $\left(\mathrm{kg} \mathrm{ha}^{-1}\right)$} \\
\hline 0 & 2714 & 7076 & 228 & 93 & 129 \\
\hline 5 & 2838 & 8200 & 243 & 104 & 28 \\
\hline 10 & 2914 & 8840 & 251 & 110 & 15 \\
\hline s.e.m. & 79 & 184 & 2.2 & 3.2 & 19.5 \\
\hline Significance & NS & ** & $* * *$ & ${ }^{* *}$ & $* * *$ \\
\hline \multicolumn{6}{|l|}{ Urine application date } \\
\hline September & 3175 & 7991 & 234 & 114 & 114 \\
\hline October & 3125 & 8538 & 252 & 119 & 91 \\
\hline November & 3300 & 9420 & 265 & 125 & 55 \\
\hline s.e.m. & 98 & 225 & 2.7 & 3.9 & 16.6 \\
\hline Significance & NS & ${ }^{* * *}$ & *** & NS & ${ }^{*}$ \\
\hline \multicolumn{6}{|c|}{ Urine application date $\times$ DCD rate $\left(\mathrm{kg} \mathrm{ha}^{-1}\right)$} \\
\hline September 0 & 3112 & 7397 & 223 & 106 & 137 \\
\hline September 5 & 2843 & 6943 & 235 & 104 & 116 \\
\hline September 10 & 3225 & 7796 & 239 & 113 & 101 \\
\hline October 0 & 3107 & 7997 & 238 & 114 & 139 \\
\hline October 5 & 3244 & 8858 & 253 & 122 & 95 \\
\hline October 10 & 3275 & 9960 & 271 & 127 & 63 \\
\hline November 0 & 3306 & 8578 & 241 & 121 & 111 \\
\hline November 5 & 3288 & 9811 & 266 & 133 & 55 \\
\hline November 10 & 3402 & 10503 & 286 & 135 & 28 \\
\hline s.e.m. & 240 & 381 & 5.0 & 6.7 & 20.4 \\
\hline Significance & NS & & ${ }^{* * *}$ & NS & \\
\hline $\begin{array}{l}\text { NS, not significant. } \\
{ }^{*} P<0.05 . \\
{ }^{* *} P<0.01 . \\
{ }^{* * *} \quad P<0.001 .\end{array}$ & & & & & \\
\hline
\end{tabular}

production in Experiment 1 by $+25 \%$, compared to the OUO treatment, and treatment NU5 and NU10 significantly increased annual herbage production compared to the NU0 treatment in Experiment 1 by +14 and $+22 \%$, respectively (Table 3 ).

\subsubsection{Herbage crude protein content and nitrogen uptake}

Spring herbage $\mathrm{CP}$ content was significantly $(P<0.001)$ greater in Experiment $1(+5 \%)$ (Table 3 ) and Experiment $2(+5 \%)$ in Year 1 compared with Year 2 (Table 4).

Spring herbage CP content was significantly $(P<0.001)$ greater following urine application in Experiment $1(+10 \%)$ (Table 3$)$ and in Experiment $2(+18 \%)$ (Table 4$)$.

There was a significant $(P<0.001)$ effect of urine application date on spring herbage $\mathrm{CP}$ content in both Experiments (Tables 3 and 4 ). Applying urine in October and November significantly $(P<0.001)$ increased spring herbage $\mathrm{CP}$ content compared to September application in Experiment 1 (Table 3). Urine application in September significantly $(P<0.01)$ increased spring herbage CP content by +7 and $+4 \%$, respectively, compared to October application in Experiment 2 (Table 4).
Applying 5 or $10 \mathrm{~kg} \mathrm{DCD} \mathrm{ha}^{-1}$ significantly $(P<0.001)$ increased spring herbage $\mathrm{CP}$ content by +7 and $+10 \%$, respectively, compared to applying zero DCD in Experiment 1 (Table 3 ). There was no significant effect of DCD first application date or DCD second application date on spring herbage $\mathrm{CP}$ content in either Experiment 1 or 2.

There was a significant $(P<0.01)$ interaction between urine application date and DCD rate on spring herbage CP content in Experiment 1 (Table 3 ). Treatment OU5 and OU10 had significantly $(P<0.05)$ greater spring herbage $\mathrm{CP}$ content compared to the OU0 treatment, and treatment NU5 and NU10 had significantly $(P<0.05)$ greater spring herbage $\mathrm{CP}$ content compared to the NU0 treatment (Table 3).

Herbage $\mathrm{N}$ uptake was significantly greater in Year 1 compared to Year 2 (Tables 3 and 4).

Herbage $\mathrm{N}$ uptake was significantly $(P<0.001)$ greater on $\mathrm{U}$ treatments compared to 0U treatments in Experiment $1(+133 \%)$ and in Experiment $2(+44 \%)$ (Tables 3 and 4$)$. September urine application significantly $(P<0.01)$ increased herbage $N$ uptake compared to all other application dates in Experiment 2 (Table 4). There was a significant $(P<0.001)$ effect of DCD rate on herbage $\mathrm{N}$ uptake in Experiment 1 but not in Experiment 2 (Tables 3 and 4). Applying 
Table 4

The effect of DCD applied following urine application on herbage production ( $\left.\mathrm{kg} \mathrm{DM} \mathrm{ha}^{-1}\right)$, crude protein ( $\left.\mathrm{g} \mathrm{kg}^{-1} \mathrm{DM}\right)$ and nitrogen uptake ( $\mathrm{kg} \mathrm{N}$ ha $\left.{ }^{-1}\right)$ in Experiment 2 .

\begin{tabular}{|c|c|c|c|c|c|}
\hline \multirow[b]{2}{*}{ Measurement period } & \multicolumn{2}{|c|}{$\begin{array}{l}\text { Herbage production } \\
\left(\mathrm{kg} \mathrm{DM} \mathrm{ha}^{-1}\right)\end{array}$} & \multirow{2}{*}{$\begin{array}{l}\text { Crude protein }\left(\mathrm{g} \mathrm{kg} \mathrm{ha}^{-1}\right) \\
\text { Spring }\end{array}$} & \multirow{2}{*}{$\begin{array}{l}\text { Nitrogen Uptake }\left(\mathrm{kg} \mathrm{ha}^{-1}\right) \\
\text { Spring }\end{array}$} & \multirow{2}{*}{$\begin{array}{l}\text { Surplus } \mathrm{N}\left(\mathrm{kg} \mathrm{ha}^{-1}\right) \\
\text { Annual }\end{array}$} \\
\hline & Spring & Annual & & & \\
\hline \multicolumn{6}{|l|}{ Year } \\
\hline Year 1 & 1685 & 5177 & 272 & 72 & 11 \\
\hline Year 2 & 1268 & 7360 & 258 & 47 & 13 \\
\hline s.e.m. & 35 & 96 & 1.9 & 1.7 & 18.2 \\
\hline Significance & $* * *$ & $* * *$ & $* * *$ & ${ }^{* * *}$ & NS \\
\hline \multicolumn{6}{|l|}{ Urine } \\
\hline Zero urine & 1274 & 5548 & 234 & 45 & -51 \\
\hline Urine & 1543 & 6508 & 275 & 65 & 67 \\
\hline s.e.m. & 66 & 163 & 3.2 & 2.9 & 12 \\
\hline Significance & $* * *$ & $* * *$ & $* * *$ & $* * *$ & $* * *$ \\
\hline \multicolumn{6}{|l|}{ DCD rate $\left(\mathrm{kg} \mathrm{ha}^{-1}\right)$} \\
\hline 0 & 1515 & 6388 & 265 & 60 & 62 \\
\hline 5 & 1457 & 6155 & 266 & 60 & 5 \\
\hline 10 & 1457 & 6262 & 264 & 59 & 2 \\
\hline s.e.m. & 54 & 132 & 2.6 & 2.4 & 23.4 \\
\hline Significance & NS & NS & NS & NS & NS \\
\hline \multicolumn{6}{|l|}{ Urine application date } \\
\hline September & 1623 & 7013 & 284 & 73 & 30 \\
\hline October & 1486 & 6014 & 265 & 63 & 115 \\
\hline November & 1521 & 6497 & 276 & 58 & 55 \\
\hline s.e.m. & 66 & 163 & 3.2 & 2.9 & 23.4 \\
\hline Significance & NS & $* * *$ & ${ }_{* * *}^{*}$ & ${ }_{* *}^{2.0}$ & $* *$ \\
\hline \multicolumn{6}{|c|}{ Urine application date $\times$ DCD rate $\left(\mathrm{kg} \mathrm{ha}^{-1}\right)$} \\
\hline September 0 & 1707 & 5951 & 279 & 76 & 51 \\
\hline September 5 & 1553 & 5258 & 265 & 72 & 25 \\
\hline September 10 & 1446 & 5273 & 270 & 72 & 25 \\
\hline October 0 & 1576 & 7060 & 288 & 72 & 105 \\
\hline October 5 & 1467 & 5942 & 267 & 63 & 114 \\
\hline October 10 & 1529 & 6340 & 276 & 61 & 121 \\
\hline November 0 & 1586 & 7029 & 286 & 72 & 93 \\
\hline November 5 & 1439 & 5844 & 262 & 60 & 66 \\
\hline November 10 & 1589 & 6878 & 282 & 62 & 26 \\
\hline s.e.m. & 162 & 397 & 7.7 & 5.0 & 46.3 \\
\hline Significance & NS & NS & 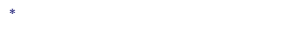 & NS & NS \\
\hline
\end{tabular}

NS, not significant.

${ }^{*} P<0.05$.

${ }^{* *} P<0.01$.

**** $P<0.001$.

DCD at a rate of 5 or $10 \mathrm{~kg} \mathrm{ha}^{-1}$ significantly $(P<0.001)$ increased herbage $\mathrm{N}$ uptake by 11 and $17 \mathrm{~kg} \mathrm{Nha}^{-1}$, respectively, compared to applying zero DCD (Table 3). There was no significant effect of DCD first application date or DCD second application date on herbage $\mathrm{N}$ uptake in either Experiment 1 or 2.

There was no significant interaction between urine application date and DCD rate on herbage $\mathrm{N}$ uptake in either Experiment 1 or 2 (Tables 3 and 4 ).

\subsubsection{Soil ammonium and total oxidised nitrogen content}

Urine application had a significant effect $(P<0.001)$ on soil $\mathrm{NH}_{4}{ }^{+}-\mathrm{N}$ content compared to $0 \mathrm{U}$ treatments in Experiments 1 and 2 (Fig. $1 \mathrm{~A}$ and $\mathrm{B}$ ). Soil $\mathrm{NH}_{4}{ }^{+}-\mathrm{N}$ content declined from day 7 to day 28 in Experiment 1 (Fig. 1A), and from day 7 to 84 in Experiment 2 (Fig. 1B) following urine application. There was no significant effect of DCD rate on $\mathrm{NH}_{4}{ }^{+}-\mathrm{N}$ content in either Experiment 1 or 2 (data not shown).

Urine application had a significant effect $(P<0.001)$ on soil TON content compared to $0 \mathrm{U}$ treatments in Experiments 1 and 2 (Fig. $1 \mathrm{~A}$ and B). There was a significant $(P<0.001)$ increase in soil TON content from sampling day 7 to 84 following urine application in
Experiment 1 (Fig. 1A) and to day 84 in Experiment 2 (Fig. 1B). There was a significant $(P<0.05)$ effect of DCD rate on soil TON content in Experiment 1 (data not shown); treatment U5 had significantly lower soil TON content on sampling day 7 compared to the treatment UO.

\subsubsection{Nitrogen balance}

Surplus N was significantly $(P<0.001)$ lower on treatments receiving zero urine compared to those receiving urine in Experiments 1 and 2 (Tables 3 and 4). September applied urine significantly $(P<0.05)$ increased surplus $N$ compared to November applied urine in Experiment 1 (Table 3). October applied urine significantly $(P<0.01)$ increased surplus $N$ compared to September applied urine in Experiment 2 (Table 4).

The application of 5 and $10 \mathrm{~kg} \mathrm{DCD} \mathrm{ha}^{-1}$ significantly $(P<0.001)$ reduced $\mathrm{N}$ surplus in Experiment 1 (Table 3 ); there was no effect in Experiment 2 .

There was a significant $(P<0.01)$ effect of the interaction between urine application date and DCD rate on $\mathrm{N}$ surplus in Experiment 1 only (Table 3 ). The $\mathrm{N}$ surplus on treatment OU10 was 

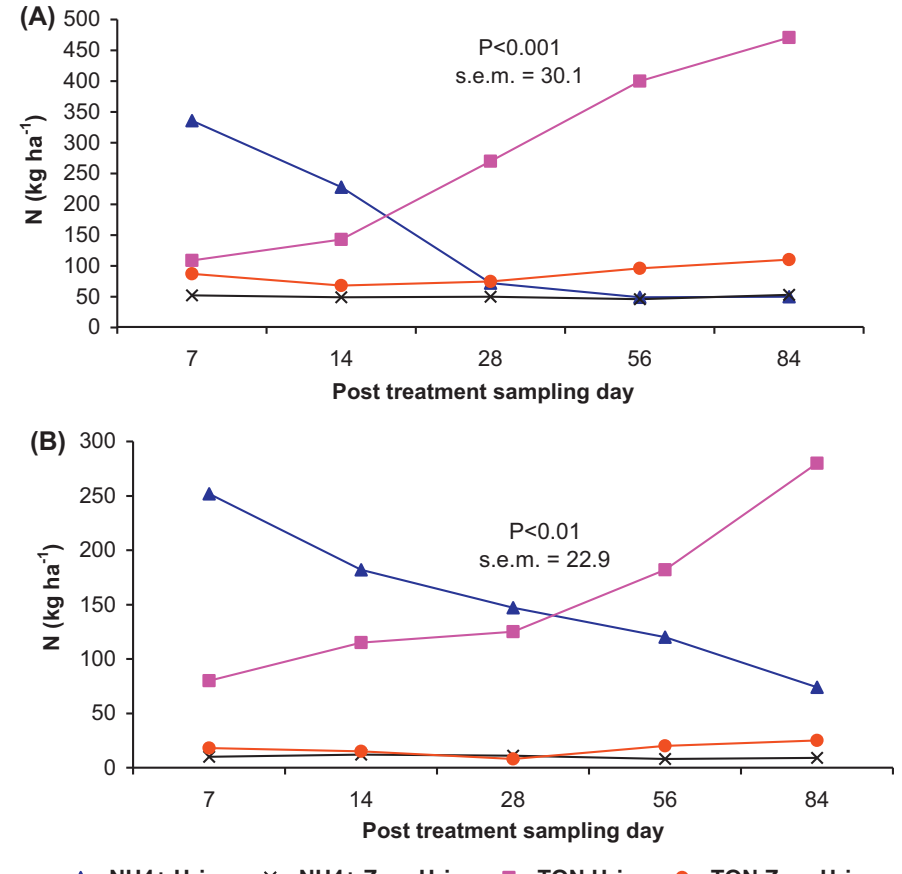

Fig. 1. The effects of urine or zero urine applied at $\mathrm{N}$ equivalent rates of 1000 or $0 \mathrm{~kg} \mathrm{Nha}{ }^{-1}$ on $\mathrm{NH}_{4}{ }^{+}-\mathrm{N}$ and TON content in the upper layers $(0-100 \mathrm{~mm})$ of the soil profile in Experiment 1 (A) and in Experiment 2 (B).

significantly lower than treatment OU0, and was significantly lower on treatment NU10 compared to treatment NU0 (Table 3).

\subsection{Experiments 3 and 4}

\subsubsection{Herbage production}

Spring herbage production was significantly $(P<0.001)$ reduced in Year 2 compared to Year 1 in Experiments 3 and 4 (Tables 5 and 6 ). In Experiment 3 annual herbage production was significantly $(P<0.001)$ reduced in Year 2 compared to Year 1 (Table 5), while in Experiment 4 annual herbage production was significantly $(P<0.001)$ greater in Year 2 than in Year 1 (Table 6$)$.

Urine application had no significant effect on spring herbage production in Experiment 3 (Table 5). Annual herbage production was significantly $(P<0.05)$ increased $(+5 \%)$ following urine application compared to zero urine application in Experiment 3 (Table 5). In Experiment 4, spring herbage production was significantly $(P<0.001)$ reduced following urine application, but there was no significant effect on annual herbage production (Table 6 ).

In Experiment 3 September urine application significantly $(P<0.01)$ increased spring herbage production compared to November urine application (Table 5).

There was no significant effect of DCD rate, DCD first application date or DCD second application date on spring or annual herbage production in either Experiment 3 or 4 (Tables 5 and 6).

\subsubsection{Herbage crude protein content and nitrogen uptake}

Spring herbage CP content was significantly $(P<0.001)$ greater in Year $1(+5 \%)$ compared to Year 2 in Experiment 4 (Table 6).

Urine application significantly $(P<0.001)$ increased spring herbage $\mathrm{CP}$ content in Experiments 3 and 4 (Tables 5 and 6) compared to the OU treatment. October and November applied urine significantly $(P<0.01)$ increased spring herbage CP content compared to September applied urine in Experiment 3 (Table 5).

Applying DCD at a rate of 5 or $10 \mathrm{~kg} \mathrm{ha}^{-1}$ significantly $(P<0.001)$ increased spring herbage $\mathrm{CP}$ content compared to applying zero
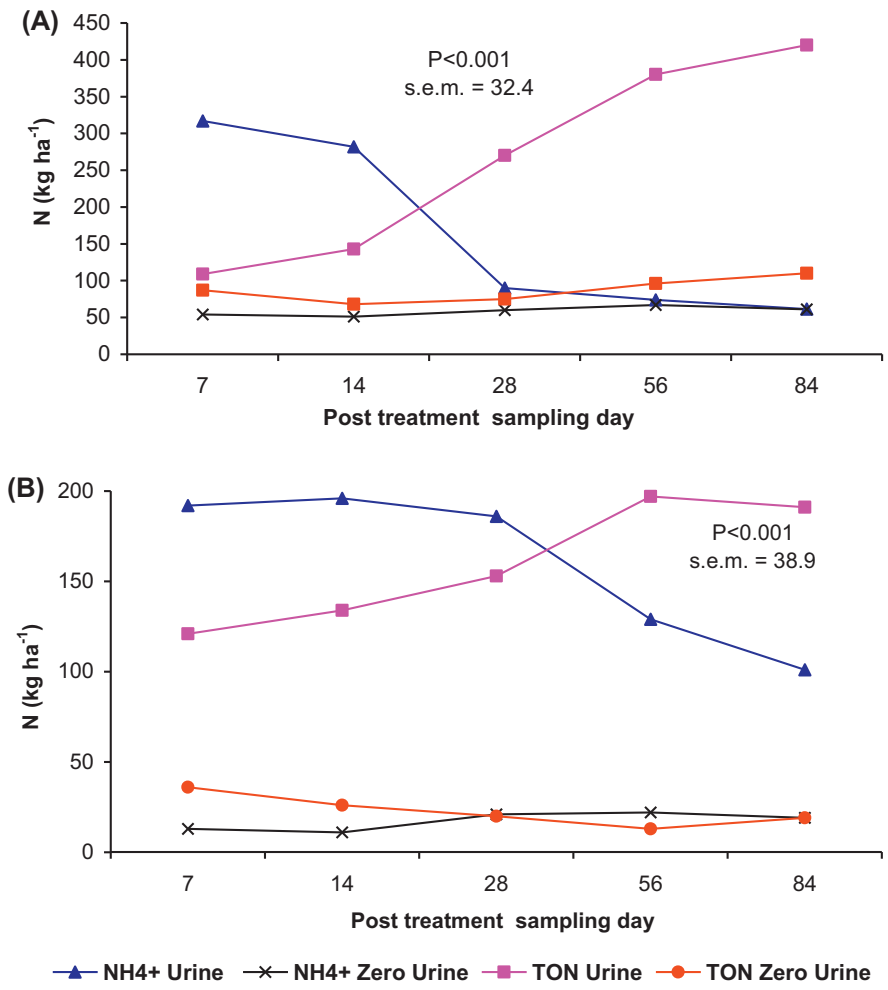

Fig. 2. The effects of urine or zero urine applied at $\mathrm{N}$ equivalent rates of 1000 or $0 \mathrm{~kg} \mathrm{Nha}^{-1}$ on $\mathrm{NH}_{4}^{+}-\mathrm{N}$ and TON content in the upper layers $(0-100 \mathrm{~mm})$ of the soil profile in Experiment 3 (A) and in Experiment 4 (B).

DCD in Experiments 3 and 4 (Tables 5 and 6). There was no significant effect of DCD first application date or DCD second application date on spring herbage $\mathrm{CP}$ content in either Experiment 3 or 4.

There was a significant interaction $(P<0.001)$ between urine application date and DCD rate on spring herbage CP content in Experiment 3 (Table 5); treatment NU0 had a significantly $(P<0.01)$ lower spring herbage $\mathrm{CP}$ content than NU10.

Herbage $\mathrm{N}$ uptake was significantly $(P<0.001)$ reduced in Year 2 $(-55 \%)$ compared to Year 1 in Experiment 3 (Table 5). In Experiment 4 , herbage $\mathrm{N}$ uptake was significantly $(P<0.001)$ greater in Year 2 compared to Year 1 (Table 6).

Urine application significantly $(P<0.001)$ increased herbage $\mathrm{N}$ uptake in both Experiments 3 and 4 compared to OU treatments (Tables 5 and 6). There was no significant effect of urine application date on herbage $\mathrm{N}$ uptake in either Experiment 3 or 4.

Applying DCD at a rate of 5 or $10 \mathrm{~kg} \mathrm{ha}^{-1}$ significantly $(P<0.001)$ increased herbage $\mathrm{N}$ uptake by +19 and $+22 \%$, respectively, compared to applying zero DCD in Experiment 4 (Table 6). There was no significant effect of DCD first application date or DCD second application date on herbage $\mathrm{N}$ uptake in either Experiment 3 or 4.

Treatments SU5 and SU10 significantly $(P<0.01)$ increased herbage $\mathrm{N}$ uptake in Experiment 4 by +27 and 29\%, respectively, compared to SU0 treatment (Table 6).

\subsubsection{Soil ammonium and total oxidised nitrogen content}

Urine application significantly $(P<0.001)$ increased soil $\mathrm{NH}_{4}{ }^{+}-\mathrm{N}$ content compared to the 0U treatments up to day 14 in Experiment 3 and up to day 56 in Experiment 4 (Fig. $2 \mathrm{~A}$ and B). The $\mathrm{NH}_{4}{ }^{+}-\mathrm{N}$ content declined from day 7 to day 84 post urine application. There was no significant effect of DCD rate on soil $\mathrm{NH}_{4}{ }^{+}-\mathrm{N}$ content in both Experiments 3 and 4 (data not shown).

Urine application significantly $(P<0.001)$ increased soil TON content compared to OU treatments across all sampling days in Experiments 3 and 4 (Fig. 2A and B). There was no significant effect 
Table 5

The effect of DCD applied following urine application on herbage production ( $\left.\mathrm{kg} \mathrm{DM} \mathrm{ha}^{-1}\right)$, crude protein ( $\left.\mathrm{g} \mathrm{kg}^{-1} \mathrm{DM}\right)$ and nitrogen uptake ( $\left.\mathrm{kg} \mathrm{N}^{-1}\right)$ in Experiment 3 .

\begin{tabular}{|c|c|c|c|c|c|}
\hline \multirow[b]{2}{*}{ Measurement period } & \multicolumn{2}{|c|}{$\begin{array}{l}\text { Herbage production } \\
\left(\mathrm{kg} \mathrm{DM} \mathrm{ha}^{-1}\right)\end{array}$} & \multirow{2}{*}{$\begin{array}{l}\text { Crude protein }\left(\mathrm{g} \mathrm{kg} \mathrm{ha}^{-1}\right) \\
\text { Spring }\end{array}$} & \multirow{2}{*}{$\begin{array}{l}\text { Nitrogen Uptake }\left(\mathrm{kg} \mathrm{ha}^{-1}\right) \\
\text { Spring }\end{array}$} & \multirow{2}{*}{$\begin{array}{l}\text { Surplus N }\left(\mathrm{kg} \mathrm{ha}^{-1}\right) \\
\text { Annual }\end{array}$} \\
\hline & Spring & Annual & & & \\
\hline \multicolumn{6}{|l|}{ Year } \\
\hline Year 1 & 4437 & 13467 & 293 & 204 & 396 \\
\hline Year 2 & 2122 & 9682 & 290 & 92 & 438 \\
\hline s.e.m. & 59 & 138 & 1.7 & 2.5 & 22.6 \\
\hline Significance & $* * *$ & $* * *$ & NS & ${ }^{* * *}$ & NS \\
\hline \multicolumn{6}{|l|}{ Urine } \\
\hline Zero urine & 3142 & 11170 & 279 & 134 & 307 \\
\hline Urine & 3325 & 11710 & 296 & 153 & 496 \\
\hline s.e.m. & 103 & 241 & 2.8 & 4.2 & 5.9 \\
\hline Significance & NS & & ${ }^{* * *}$ & ${ }^{* * *}$ & $* * *$ \\
\hline \multicolumn{6}{|l|}{ DCD rate $\left(\mathrm{kg} \mathrm{ha}^{-1}\right)$} \\
\hline 0 & 3345 & 11588 & 279 & 145 & 498 \\
\hline 5 & 3256 & 11637 & 296 & 150 & 413 \\
\hline 10 & 3238 & 11499 & 300 & 149 & 401 \\
\hline s.e.m. & 84 & 199 & 2.3 & 3.4 & 30 \\
\hline Significance & NS & NS & ${ }^{* * *}$ & NS & NS \\
\hline Urine application date & & & & & 0.08 \\
\hline September & 3565 & 11583 & 289 & 156 & 499 \\
\hline October & 3301 & 11648 & 297 & 152 & 494 \\
\hline November & 3108 & 11898 & 302 & 150 & 493 \\
\hline s.e.m. & 103 & 243 & 2.8 & 4.2 & 12.5 \\
\hline Significance & ${ }^{* *}$ & NS & ${ }^{* *}$ & NS & NS \\
\hline \multicolumn{6}{|c|}{ Urine application date $\times$ DCD rate $\left(\mathrm{kg} \mathrm{ha}^{-1}\right)$} \\
\hline September 0 & 3781 & 11940 & 279 & 157 & 494 \\
\hline September 5 & 3123 & 10841 & 278 & 152 & 504 \\
\hline September 10 & 3440 & 12480 & 288 & 159 & 498 \\
\hline October 0 & 3350 & 11239 & 295 & 137 & 524 \\
\hline October 5 & 3478 & 12060 & 302 & 160 & 488 \\
\hline October 10 & 3008 & 11937 & 302 & 159 & 485 \\
\hline November 0 & 3565 & 11569 & 292 & 156 & 477 \\
\hline November 5 & 3304 & 12043 & 311 & 150 & 497 \\
\hline November 10 & 2877 & 11277 & 317 & 144 & 496 \\
\hline s.e.m. & 245 & 671 & 6.8 & 7.2 & 24.9 \\
\hline Significance & NS & NS & & NS & NS \\
\hline
\end{tabular}

NS, not significant.

${ }^{*} P<0.05$.

** $P<0.01$.

*** $P<0.001$.

of DCD rate on soil TON content in Experiments 3 and 4 (data not shown).

\subsubsection{Nitrogen balance}

Urine application significantly $(P<0.001)$ increased surplus $\mathrm{N}$ compared to zero urine application by 62 and 59\% in Experiments 3 and 4, respectively (Tables 5 and 6 ).

The application of DCD at a rate of 5 and $10 \mathrm{~kg} \mathrm{ha}^{-1}$ significantly $(P<0.05)$ reduced $\mathrm{N}$ surplus by 20 and $21 \%$, respectively, in Experiment 4 (Table 6).

\section{Discussion}

\subsection{Herbage production, herbage crude protein content and herbage $N$ uptake}

Whitehead and Bristow (1990) reported that the recovery of urinary $\mathrm{N}$ by the soil/plant component of the sward is subject to a number of factors including rainfall amount, which affects plant growth and leaching, and variation in temperature, which contributes to evaporation and to plant growth. In Experiment 1 (zero
$\mathrm{N}$ fertiliser) average spring and annual herbage production was increased at both sites when urine was applied, similar to Qiu et al. (2010), due to high $\mathrm{N}$ content in urine (Haynes and Williams, 1993). In Experiment $3\left(350 \mathrm{~kg} \mathrm{~N} \mathrm{ha}^{-1}\right.$ year $\left.^{-1}\right)$ there was a positive effect of urine application on annual herbage production. While some of the additional $\mathrm{N}$ applied in the urine would have been used for herbage growth, it is likely that most of the $\mathrm{N}$ was surplus to the requirements of the sward. Frame (1992) and Van Burg et al. (1981) suggest that $\mathrm{N}$ supplies greater than $350-400 \mathrm{~kg} \mathrm{~N} \mathrm{ha}^{-1}$ year $^{-1}$ are surplus to the requirements of the growing plant. Lantinga et al. (1987) reported that grass is more susceptible to urine scorch at $\mathrm{N}$ fertilisation levels similar to the rate applied in Experiments 3 and 4. Middelkoop and Deenan (1990) observed that urine had a negative effect on herbage production in the treated areas due to scorching; this effect was strongest at $400 \mathrm{~kg} \mathrm{~N} \mathrm{ha}^{-1}$ and increased with increasing $\mathrm{N}$ concentration. The application of urine to $\mathrm{N}$ fertiliser treated swards may have inhibited herbage production as a result of some scorching in Experiments 3 and 4.

The application of DCD at 5 or $10 \mathrm{~kg} \mathrm{ha}^{-1}$ significantly increased annual herbage production in Experiment 1; similar to Di and Cameron $(2002,2005)$. In a whole paddock scenario receiving zero 
Table 6

The effect of DCD applied following urine application on herbage production ( $\left.\mathrm{kg} \mathrm{DM} \mathrm{ha}^{-1}\right)$, crude protein ( $\left.\mathrm{g} \mathrm{kg} \mathrm{g}^{-1} \mathrm{DM}\right)$ and nitrogen uptake ( $\mathrm{kg} \mathrm{N}$ ha $\left.{ }^{-1}\right)$ in Experiment 4 .

\begin{tabular}{|c|c|c|c|c|c|}
\hline \multirow[b]{2}{*}{ Measurement period } & \multicolumn{2}{|c|}{$\begin{array}{l}\text { Herbage production } \\
\left(\mathrm{kg} \mathrm{DM} \mathrm{ha}^{-1}\right)\end{array}$} & \multirow{2}{*}{$\begin{array}{l}\text { Crude protein }\left(\mathrm{g} \mathrm{kg} \mathrm{ha}^{-1}\right) \\
\text { Spring }\end{array}$} & \multirow{2}{*}{$\begin{array}{l}\text { Nitrogen Uptake }\left(\mathrm{kg} \mathrm{ha}^{-1}\right) \\
\text { Spring }\end{array}$} & \multirow{2}{*}{$\begin{array}{l}\text { Surplus } \mathrm{N}\left(\mathrm{kg} \mathrm{ha}^{-1}\right) \\
\text { Annual }\end{array}$} \\
\hline & Spring & Annual & & & \\
\hline \multicolumn{6}{|l|}{ Year } \\
\hline Year 1 & 2038 & 7254 & 299 & 21 & 429 \\
\hline Year 2 & 1146 & 8507 & 285 & 52 & 440 \\
\hline s.e.m. & 35 & 117 & 1.4 & 1.6 & 24.0 \\
\hline Significance & ${ }^{* * *}$ & $* * *$ & $* * *$ & $* * *$ & NS \\
\hline \multicolumn{6}{|l|}{ Urine } \\
\hline Zero urine & 1800 & 8083 & 279 & 25 & 327 \\
\hline Urine & 1592 & 7880 & 296 & 40 & 521 \\
\hline s.e.m. & 60 & 167 & 1.9 & 1.7 & 7.4 \\
\hline Significance & ${ }^{* * *}$ & NS & $* * *$ & $* * *$ & $* * *$ \\
\hline \multicolumn{6}{|l|}{ DCD rate $\left(\mathrm{kg} \mathrm{ha}^{-1}\right)$} \\
\hline 0 & 1544 & 7776 & 288 & 32 & 530 \\
\hline 5 & 1560 & 7894 & 294 & 38 & 426 \\
\hline 10 & 1672 & 7971 & 294 & 39 & 420 \\
\hline s.e.m. & 50 & 147 & 1.5 & 1.6 & 31.2 \\
\hline Significance & NS & NS & $*^{*}$ & ${ }^{* *}$ & \\
\hline \multicolumn{6}{|l|}{ Urine application date } \\
\hline September & 1470 & 7643 & 294 & 41 & 520 \\
\hline October & 1459 & 7678 & 296 & 40 & 525 \\
\hline November & 1639 & 8119 & 299 & 39 & 517 \\
\hline s.e.m. & 61 & 176 & 1.9 & 1.9 & 7 \\
\hline Significance & NS & NS & NS & NS & NS \\
\hline \multicolumn{6}{|c|}{ Urine application date $\times$ DCD rate $\left(\mathrm{kg} \mathrm{ha}^{-1}\right)$} \\
\hline September 0 & 1489 & 7271 & 289 & 34 & 536 \\
\hline September 5 & 1337 & 7435 & 292 & 43 & 517 \\
\hline September 10 & 1630 & 8134 & 298 & 44 & 516 \\
\hline October 0 & 1342 & 7615 & 293 & 37 & 538 \\
\hline October 5 & 1504 & 7804 & 299 & 44 & 519 \\
\hline October 10 & 1512 & 7092 & 300 & 40 & 525 \\
\hline November 0 & 1578 & 8043 & 299 & 37 & 517 \\
\hline November 5 & 1537 & 7794 & 296 & 38 & 520 \\
\hline November 10 & 1774 & 8131 & 300 & 43 & 514 \\
\hline s.e.m. & 151 & 410 & 4.7 & 3.0 & 13.4 \\
\hline Significance & NS & NS & $*$ & NS & NS \\
\hline
\end{tabular}

$\mathrm{N}$ fertiliser, growing $8000 \mathrm{~kg} \mathrm{DM} \mathrm{ha}^{-1}$ and grazed by dairy cows the addition of DCD at either rate would increase annual herbage production by between 200 and $400 \mathrm{~kg} \mathrm{DM} \mathrm{ha}^{-1}$, assuming that $25 \%$ of the paddock receives urine deposition per year plus 5 or $10 \mathrm{~kg} \mathrm{DCD} \mathrm{ha}^{-1}$ (Haynes and Williams, 1993). The application of DCD did not increase herbage production in Experiment 2, 3 or 4, similar to Cookson and Cornforth (2002), Menneer et al. (2008) and Monaghan et al. (2009), and therefore the hypothesis that the application of DCD at different rates and times in autumn and winter would increase herbage production in Experiment 2, 3 and 4 is rejected. Previous authors report that DCD should be applied in cool temperatures and periods of low rainfall to maximise its effectiveness (Vallejo et al., 2005). The rainfall experienced following DCD application in this experiment may have leached the DCD beyond the rooting zone, therefore reducing its effectiveness. High soil and air temperatures recorded in October and November may have reduced the half life of the DCD, therefore reducing its capacity to slow the conversion of $\mathrm{NH}_{4}{ }^{+}$to TON. As mentioned temperature is one of the most influential environmental factors affecting the effectiveness of DCD (Williamson et al., 1996). An increase in temperature can have a negative effect on the persistence of DCD in the soil, reducing the time frame in which it can provide effective nitrification reduction.

Developing a DCD application strategy to contribute to increased herbage production and help to mitigate environmental emissions associated with increased agricultural production in Ireland would most likely require consideration of factors other than soil temperature. It may be worth considering DCD application at a time when rainfall is lower than in autumn/winter so that the DCD is less likely to be leached beyond the rooting zone. In such instances the DCD will reduce nitrification in a soil zone in which herbage could benefit from the availability of additional $\mathrm{N}$ for plant growth. The soil sampling undertaken in Experiments 3 and 4 indicates that DCD had almost no effect on soil mineral $\mathrm{N}$ content in the $0-100 \mathrm{~mm}$ soil horizon. However, as DCD has been shown to be effective at reducing $\mathrm{N}_{2} \mathrm{O}$ emissions and $\mathrm{NO}_{3}$ - leaching in Irish soils (Selbie et al., 2011; Richards et al., 2008) it is quite possible that the DCD is inhibiting nitrification beyond a soil depth of $100 \mathrm{~mm}$.

During this study urine deposition increased spring herbage $\mathrm{CP}$ content in all experiments similar to other authors (Ledgard et al., 1982; Williams and Haynes, 1994). Similar to Moir et al. (2007), the application of DCD had an effect on spring herbage CP content in 
Experiments 1 and 3 at MPK as a result of increased $\mathrm{N}$ uptake. The application of DCD may have provided additional $\mathrm{N}$ in the rooting zone for plant uptake; but due to low temperatures in spring this did not result in increased grass growth but rather resulted in the accumulation of $\mathrm{N}$ in the plant foliage.

Throughout this study urine application increased herbage $\mathrm{N}$ uptake compared to zero urine application, similar to Cuttle and Bourne (1993). The increase in herbage $\mathrm{N}$ uptake may be due to the uptake of urea into the plant by roots; this mode of $\mathrm{N}$ uptake is small compared to the uptake of $\mathrm{NO}_{3}{ }^{-}-\mathrm{N}$ and $\mathrm{NH}_{4}{ }^{+}-\mathrm{N}$. However, foliar adsorption of urea can occur at a high rate and can contribute substantially to plant $\mathrm{N}$ accumulation and not result in herbage production (Camberato, 2001).

Also, $\mathrm{N}$ uptake is reported to increase with increasing rates of $\mathrm{N}$ applied, including rates of $\mathrm{N}$ above which herbage production is maximised (Lkhagvasuren, 2007). Nitrogen uptake is also reported to occur in periods of low grass growth (Blombäck and Eckersten, 1997), also resulting in increased CP content but not herbage production. The ability of perennial ryegrasses to increase $\mathrm{N}$ uptake below the top $100 \mathrm{~mm}$ of the soil profile are limited as a small proportion of the roots occur below the top $100 \mathrm{~mm}$ of the soil profile (Garwood, 1967) and also 90\% of the root activity of perennial ryegrass occurs in the top $125 \mathrm{~mm}$ of the soil profile (Syers et al., 1984), thereby, the capability of perennial ryegrasses to utilise the available $\mathrm{N}$ for herbage production below the top $100 \mathrm{~mm}$ of the soil profile is greatly reduced.

\subsection{Soil ammonium and total oxidised nitrogen content}

Urine application increased soil $\mathrm{NH}_{4}{ }^{+}-\mathrm{N}$ and TON content compared to zero urine application. In urine treated soils, urea is rapidly hydrolysed to $\mathrm{NH}_{4}{ }^{+}-\mathrm{N}$ and reaches maximum values soon after urine application (Zaman et al., 2009). Nitrification then oxidises the $\mathrm{NH}_{4}{ }^{+}-\mathrm{N}$ to nitrite and the nitrite is further oxidised to $\mathrm{NO}_{3}{ }^{-}$ (Estavillo et al., 2002). In the experiments reported here, soil $\mathrm{NH}_{4}{ }^{+}-$ $\mathrm{N}$ content declined with time following urine application. The period following urine application was one of low sward $\mathrm{N}$ demand due to low rates of grass growth and as a result $\mathrm{N}$ was likely to be lost by leaching through the soil profile or through immobilization (Woodmaness et al., 1981). At MPK the elevated $\mathrm{NH}_{4}{ }^{+}-\mathrm{N}$ content following urine application declined and was similar to the zero urine treatments by day 84 and so no additional $\mathrm{N}$ was available for spring grass growth. At $\mathrm{BD}$, there was considerably more soil $\mathrm{NH}_{4}{ }^{+}-\mathrm{N}$ present in the rooting zone $(0-100 \mathrm{~mm})$ at sampling day 84 on the urine treatments. The rapid movement of $\mathrm{N}$ to below the rooting zone at MPK can be attributed to the free draining soil characteristics at this site, while at BD the drainage capabilities are more restricted, resulting in reduced leaching potential (Decau et al., 2003; Richards et al., 2008).

Moir et al. (2007) reported that the application of $10 \mathrm{~kg} \mathrm{DCD} \mathrm{ha}^{-1}$ to urine patches inhibited urine sourced $\mathrm{NH}_{4}{ }^{+}-\mathrm{N}$ in the soil for several weeks over the autumn/winter period, however, in Experiments 1 and 2 reported here DCD provided inhibition of urine sourced $\mathrm{NH}_{4}{ }^{+}-\mathrm{N}$ for a short period of 14 days. The soil sampling undertaken in the four experiments indicate that DCD had almost no effect on soil mineral $\mathrm{N}$ content to a soil depth of $100 \mathrm{~mm}$ suggesting that the DCD may have leached below this soil depth.

\subsection{Nitrogen balance}

Research has shown that $\mathrm{N}$ losses from a growing sward increase exponentially with an increase in N inputs (Scholefield et al., 1993), this was observed in the experiments reported here when urine and fertiliser were applied to a growing sward. As it is not possible to quantify the total quantity of surplus $\mathrm{N}$ in this study as the only $\mathrm{N}$ output measured was herbage $\mathrm{N}$ uptake, the $\mathrm{N}$ balances reported are a crude estimate of $\mathrm{N}$ surplus. As DCD can reduce $\mathrm{NO}_{3}{ }^{-}$leaching and $\mathrm{N}_{2} \mathrm{O}$ emissions, as measured by other authors, it will have a positive effect on a farm $\mathrm{N}$ balance. However, DCD is most effective on urine patches and in cool temperatures, and so the over all effect in reducing $\mathrm{N}$ surplus will be proportional to the area of the farm affected by urine patches, particularly in autumn. For example, using an annual farm-gate $\mathrm{N}$ balance scenario where DCD was applied in September following urine deposition on a farm applying $250 \mathrm{~kg}$ inorganic $\mathrm{N} \mathrm{ha}^{-1}$ year $^{-1}$ compared to a farm applying zero $\mathrm{DCD}$, the $\mathrm{N}$ surplus would be reduced by $3 \mathrm{~kg} \mathrm{~N}$ based on the effect of DCD on herbage production.

\section{Conclusions}

Urine increased spring and annual herbage production when applied to swards receiving zero fertiliser; however when urine was applied to swards receiving fertiliser, spring herbage production was not significantly increased. Urine application also increased $\mathrm{N}$ uptake and spring herbage $\mathrm{CP}$ content. DCD applied at 5 and $10 \mathrm{~kg} \mathrm{ha}^{-1}$ increased annual herbage production at MPK by 200 to $400 \mathrm{~kg} \mathrm{DM} \mathrm{ha}^{-1}$. Dicyandiamide increased spring herbage $\mathrm{CP}$ content at MPK in Experiments 1 and 3. The addition of DCD also increased herbage N uptake at MPK in Experiment 1 and at $\mathrm{BD}$ in Experiment 4. In Experiments 1 and 3, soil $\mathrm{NH}_{4}{ }^{+}-\mathrm{N}$ content on the urine treatments declined over the sampling period, while soil TON content was significantly increased on the urine treatments compared to the zero urine treatments in both experiments. Dicyandiamide applied to October and November deposited urine reduced $\mathrm{N}$ surplus in Experiments 1 and 4. Overall the effects of DCD on herbage production, surplus $\mathrm{N}$ and other parameters in this study were not consistent.

\section{Acknowledgements}

The authors wish to thank Messrs. M. Feeney, J. McCarthy and F. Flynn for their technical assistance. Gratitude is also expressed to the Moorepark farm staff for their assistance with measurements taken during this study. The first author (P.J. O'Connor) was in receipt of a Teagasc Walsh Fellowship.

\section{References}

Amberger, A., 1989. Research on dicyandiamide as a nitrification inhibitor and future outlook. Commun. Soil Sci. Plant Anal. 20, 1933-1955.

Ansah, T., Osafo, E.L.K., Hansen, H.H., 2010. Herbage yield and chemical composition of four varieties of Napier (Pennisetum purpureum) grass harvested at three different days after planting. Agric. Biol. J. N. Am. 1, 923-929.

Blombäck, K., Eckersten, H., 1997. Simulated growth and nitrogen dynamics of a perennial rye grass. Agric. Forest Meteorol. 88, 37-45.

Burns, B.A., Gilliland, T.J., McGilloway, D.A., O’Donovan, M., Lewis, E., Blount, N., O'Kiely, P., 2010. Using NIRS to predict composition characteristics of Lolium perenne L. cultivars. In: Advances in Animal Biosciences. Food, Feed, Energy and Fibre from the Land-a Vision for 2020. British Soc. Anim. Sci., Belfast, UK, 321 pp.

Bussink, D.W., Oenema, O., 1996. Ammonia volatilization from dairy farming systems in temperate areas: a review. In: Scandinavian-Association-ofAgricultural-Scientists Seminar on Ammonia Emissions from Agriculture Uppsala, Sweden, pp. 19-33.

Camberato, J.J., 2001. Nitrogen in Soil and Fertilizers, vol. 8. SC Turf-grass Foundation News, pp. 6-10.

Cookson, W.R., Cornforth, I.S., 2002. Dicyandiamide slows nitrification in dairy cattle urine patches: effects on soil solution composition, soil $\mathrm{pH}$ and pasture yield. Soil Biol. Biochem. 34, 1461-1465.

Cuttle, S.P., Bourne, P.C., 1993. Uptake and leaching of nitrogen from artificial urine applied to grassland on different dates during the growing season. Plant Soil 150, 77-86.

Decau, M.L., Simon, J.C., Jacquet, A., 2003. Fate of urine nitrogen in three soils throughout a grazing season. J. Environ. Qual. 32, 1405-1413.

Dennis, S.J., Richards, K., Cameron, K.C., Di, H.J., Moir, J.L., Fay, D., Staples, V., Sills, P.,2008. Dicyandiamide (DCD) nitrification inhibitor reduces nitrous oxide emissions from soils. In: Proceedings of Agricultural Research Forum. The Tullamore Court Hotel, Tullamore, Co., Offaly, 6 pp. 
Di, H.J., Cameron, K.C., 2002. The use of a nitrification inhibitor, dicyandiamide(DCD), to decrease nitrate leaching and nitrous oxide emissions in simulated grazed and irrigated grassland. Soil Use Manage. 18, 395-403.

Di, H.J., Cameron, K.C., 2004. Effects of temperature and application rate of a nitrification inhibitor, dicyandiamide (DCD), on nitrification rate and microbial biomass in a grazed pasture soil. Aust. J. Soil Res. 42, 927-932.

Di, H.J., Cameron, K.C., 2005. Reducing environmental impacts of agriculture by using a fine particle suspension nitrification inhibitor to decrease nitrate leaching from grazed pastures. Agric. Ecosyst. Environ. 109, 202-212.

Dillon, P., Roche, J.R., Shalloo, L., Horan, B.,2005. Optimising financial return from grazing in temperate pastures. In: Utilisation of grazed grass in temperate animal systems, Proceedings of a Satellite Workshop of the XXth International Grassland Congress. Wageningen Academic Publishers, Cork, Ireland, pp. 131-147.

Estavillo, J.M., Merino, P., Pinto, M., Yamulki, S., Gebauer, G., Sapek, A., Corré, W., 2002. Short term effect of ploughing a permanent pasture on $\mathrm{N}_{2} \mathrm{O}$ production from nitrification and denitrification. Plant Soil 239, 253-265.

Frame, J., 1992. Improved Grassland Management. Farming Press Books, Ipswich, United Kingdom.

Garwood, E.A., 1967. Some effects of soil water conditions and soil temperature on the roots of grasses. Grass Forage Sci. 22, 176-181.

Hao, X., Ball, B.C., Culley, J.L.B., Carter, M.R., Parkin, G.W., 2008. Soil density and porosity. In: Carter, M.R., Gregorich, E.G. (Eds.), Soil Sampling and Methods of Analysis. Taylor and Francis Group, Boca Raton, FL, USA, pp. 743-759.

Haynes, R.J., Williams, P.H., 1993. Nutrient cycling and soil fertility in the grazed pasture ecosystem. Adv. Agron. 49, 119-199.

Hennessy, D., O'Donovan, M., French, P., Laidlaw, A.S., 2008. Manipulation of herbage production by altering the pattern of applying nitrogen fertilizer. Grass Forage Sci. 63, 152-166.

Kelliher, F.M., Clough, T.J., Clark, H., Rys, G., Sedcole, J.R., 2008. The temperature dependence of dicyandiamide (DCD) degradation in soils: a data synthesis. Soil Biol. Biochem. 40, 1878-1882.

Kennedy, E., O’Donovan, M., Murphy, J.P., Delaby, L., O’Mara, F., 2005. Effects of grass pasture and concentrate-based feeding systems for spring-calving dairy cows in early spring on performance during lactation. Grass Forage Sci. 60, 310-318.

Lantinga, E.A., Keuning, J.A., Groenwold, J., Deenen, P.J.A.G.,1987. Distribution of excreted nitrogen by grazing cattle and its effects on sward quality, herbage production and utilization. In: Animal Manure on Grassland and Fodder Crops. Fertilizer or Waste? Proceedings of an International Symposium of the European Grassland Federation Wageningen. Martinus Nijhoff Publishers, Dordrecht, The Netherlands.

Ledgard, S.F., Steele, K.W., Saunders, W.H.M., 1982. Effects of cow urine and its major constituents on pasture properties. N. Z. J. Agric. Res. 25, 61-68.

Ledgard, S.F., Penno, J.W., Sprosen, M.S., 1999. Nitrogen inputs and losses from clover/grass pastures grazed by dairy cows, as affected by nitrogen fertilizer application. J. Agric. Sci. 132, 215-225.

Lkhagvasuren, B., 2007. Plant and Soil Responses to Fertilization of Grasslands in Saskatchewan, Canada and Selenge, Mongolia. Department of Soil Science, University of Saskatchewan, Saskatoon, pp. 1-100.

Menneer, J.C., Ledgard, S.F., Sprosen, M., 2008. Soil N process inhibitors alter nitrogen leaching dynamics in a pumice soil. Aust. J. Soil Res. 46, 323-331.

Middelkoop, N., Deenan, P.J.A.G., 1990. The local influence of cattle dung and urine and its interactions with fertiliser nitrogen on herbage dry matter production. In: Soil-Grassland-Animals Relationships, vol. 2, Proceedings of the 13th General meeting of the European Grassland Federation, Banska Bystrica, Czechoslovakia, pp. 67-70.

Moir, J.L., Cameron, K.C., Di, H.J., 2007. Effects of the nitrification inhibitor dicyandiamide on soil mineral $\mathrm{N}$, pasture yield, nutrient uptake and pasture quality in a grazed pasture system. Soil Use Manage. 23, 111-120.

Monaghan, R.M., Smith, L.C., Ledgard, S.F., 2009. The effectiveness of a granular formulation of dicyandiamide (DCD) in limiting nitrate leaching from a grazed dairy pasture. N. Z. J. Agric. Res. 52, 145-159.

O'Connell, K., Humphreys, J., Watson, C.J.,2004. Quantification of nitrogen sources for grassland. In: Winter Scientific Meeting. Fertiliser Association of Ireland, Dublin, pp. $15-28$.

O’Donovan, M., Kennedy, E., 2007. Maximising dairy cow performance from grazed grass. In: Buckley, F. (Ed.), Moorepark 07 Irish Dairying-Winning on a World
Stage. Teagasc, Dairy Production Research Centre, Moorepark, Fermoy, Co., Cork, Ireland, pp. 29-35.

Qiu, W., Di, H.J., Cameron, K.C., 2010. Nitrous oxide emissions from animal urine as affected by season and a nitrification inhibitor dicyandiamide. J. Soils Sediment. $10,1229-1235$

Richards, K., Dennis, S.J., Cameron, K.C., Di, H.J., Moir, J.L., Fay, D., Stark, C.H., Staples, V., Sills, P.,2008. The potential role of the nitrification inhibitor DCD for reducing nitrate leaching from grazed grassland. In: Proceedings of Agricultural Research Forum. Tullamore, Co., Offaly, 1 pp.

Ryan, M., Brophy, C., Connolly, J., McNamara, K., Carton, O.T., 2006. Monitoring of nitrogen leaching on a dairy farm during four drainage seasons. Ir. J. Agric. Food Res. 45, 115-134.

SAS, 2003. Statistical Analysis System User's Guide, Version 9.1.3. SAS Institute Inc., Cary, NC.

Scholefield, D., Tyson, K.C., Garwood, E.A., Armstrong, A.C., Hawkins, J., Stone, A.C., 1993. Nitrate leaching from grazed grassland lysimeters: effects of fertilizer input, field drainage, age of sward and patterns of weather. J. Soil Sci. 44, 601-613.

Selbie, D.R., Lanigan, G., Di, H.J., Moir, J.L., Cameron, K.C., Richards, K.G.,2011. Improving nitrogen efficiency using a nitrification inhibitor on urine-affected soil-a grassland lysimeter study. In: Proceedings of Agricultural Research Forum. Tullamore, Co., Offaly, 2 pp.

Serna, M., Legaz, F., Primo-Millo., E., 1995. Improvement of the N fertiliser efficiency with dicyandiamide (DCD) in citrus trees. Nutr. Cycl. Agroecosyst. 43, 137-142.

Shalloo, L., Dillon, P., O’Loughlin, J., Rath, M., Wallace, M., 2004. Comparison of a pasture-based system of milk production on a high rainfall, heavy-clay soil with that on a lower rainfall, free-draining soil. Grass Forage Sci. 59, 157-168.

Syers, J.K., Ryden, J.C., Garwood, E.A., 1984. Assessment of root activity of perennial ryegrass and white clover measured using 32 phosphorus as influenced by method of isotope placement, irrigation and method of defoliation. J. Sci. Food Agric. 35, 959-969.

Vallejo, A., Garcia-Torres, L., Diez, J.A., Arce, A., Lopez-Fernandez, S., 2005. Comparison of $\mathrm{N}$ losses $\left(\mathrm{NO}_{3}{ }^{-}, \mathrm{N}_{2} \mathrm{O}, \mathrm{NO}\right)$ from surface applied, injected or amended (DCD) pig slurry of an irrigated soil in a Mediterranean climate. Plant Soil 272, 313-325.

Van Burg, P.F.J., Prins, W.H., den Boer, D.J., Sluiman, W.J., 1981. Nitrogen and intensification of livestock farming in EEC countries. In: Proceedings of Fertiliser Society, vol. 199, London, pp. 1-78.

Whitehead, D.C., 1995. Grassland nitrogen. In: O'Connell, K., Humphreys, J., Watson, C.J. (Eds.), Quantification of Nitrogen Sources for Grassland, vol. 40, Proceedings of Fertilizer Association. Ireland, pp. 15-29.

Whitehead, D.C., Bristow, A.W., 1990. Transformation of nitrogen following the application of $15 \mathrm{~N}$ - labelled cattle urine to an established sward. J. Appl. Ecol. 27, 667-678.

Williams, P.H., Haynes, R.J., 1994. Comparison of initial wetting pattern, nutrient concentrations in soil solution and the fate of $15 \mathrm{~N}$-labelled urine in sheep and cattle urine patch areas of pasture soil. Plant Soil 162, 49-59.

Williamson, J.C., Menneer, J.C., Torrens, R.S., 1996. Impact of dicyandiamide on the internal nitrogen cycle of a volcanic, silt loam soil receiving effluent. Appl. Soil Ecol. 4, 39-48.

Woodmaness, R.G., Vallis, I., Mott, J.J., 1981. Grassland nitrogen. In: Clark, F.E., Rosswall, T. (Eds.), Terrestrial Nitrogen Cycles, Processes, Ecosystem Strategies and Management Impacts. , Ecological bulletins No. 33.

Zaman, M., Blennerhassett, J.D., 2010. Effects of the different rates of urease and nitrification inhibitors on gaseous emissions of ammonia and nitrous oxide, nitrate leaching and pasture production from urine patches in an intensive grazed pasture system. Agric. Ecosyst. Environ. 136, 236-246.

Zaman, M., Di, H.J., Cameron, K.C., Framptom, C.M., 1999. Gross nitrogen mineralization and nitrification rates and their relationships to enzyme activities and the soil microbial biomass in soils treated with dairy shed effluent and ammonium fertilizer at different water potentials. Biol. Fertil. Soils 29, 178-186.

Zaman, M., Saggar, S., Blennerhassett, J.D., Singh, J., 2009. Effect of urease and nitrification inhibitors on $\mathrm{N}$ transformation, gaseous emissions of ammonia and nitrous oxide, pasture yield and $\mathrm{N}$ uptake in grazed pasture system. Soil Biol. Biochem. 41, 1270-1280. 